\title{
ECOAMBIGUITY AND TOURISM DEVELOPMENT IN CONTEMPORARY VIETNAM - CASE STUDY OF AN ETHNIC KHMER VILLAGE IN SOUTHERN VIETNAM
}

\author{
ECOAMBIGÜEDAD Y DESARROLLO TURÍSTICO EN EL VIETNAM \\ CONTEMPORÁNEO: ESTUDIO DE CASO DE UNA ALDEA ÉTNICA KHMER EN EL \\ SUR DE VIETNAM
}

\begin{abstract}
Diep Le-Thi-Ngoc ${ }^{1} *$ (D); Ngoc Tho Nguyen ${ }^{2}$ (D).
1. University of Social Sciences and Humanities, Vietnam National University - Ho Chi Minh City. lethingocdiep@hcmussh.edu.vn

2. University of Social Sciences and Humanities, Vietnam National University - Ho Chi Minh City. ngoctho@hcmussh.edu.vn
\end{abstract}

*Corresponding author: Diep Le-Thi-Ngoc, correo electrónico: lethingocdiep@hcmussh.edu.vn

\begin{abstract}
Many development projects in Vietnam today, including tourism, are partially focused on ecology. However, the mentality of cultivating for later gains is still popular. In addition to the goal of creating opportunities to benefit local communities, this development discourse conveys a sense of 'ecoambiguity'. This study mainly applies the concept of "ecoambiguity" of Thornber (2012) to discuss the current situation and impact of tourism activities in the Khmer community around Bà Om Pond in Trà Vinh, Vietnam. Unlike previous works that discussed the beauty and value of Khmer religion, temples, rural life, festivals, and art, this research argues that people-centered policies have never enabled people to achieve their goals.
\end{abstract}

Keywords: tourism; development discourse; Khmer; Bà Om Pond; Trà Vinh.

Cómo citar:

Le-Thi-Ngoc, Diep; Nguyen, Ngoc Tho. (2021). Ecoambiguity and tourism development in contemporary Vietnam - Case study of zan ethnic khmer village in southern Vietnam. Revista de Investigaciones Universidad del Quindio, 33(2), 45-55. https://doi. org/10.33975/riuq.vol33n2.515

Información del artículo: Recibido: 23 junio 2021; Aceptado: 19 agosto 2021 


\section{RESUMEN}

Hoy en día, muchos proyectos de desarrollo en Vietnam, incluido el turismo, se centran parcialmente en la ecología. Sin embargo, la mentalidad de cultivar para obtener ganancias posteriores sigue siendo popular. Además del objetivo de crear oportunidades para beneficiar a las comunidades locales, este discurso sobre el desarrollo transmite un sentido de "ecoambigüedad". Este estudio aplica principalmente el concepto de "ecoambigüedad" de Thornber (2012) para discutir la situación actual y el impacto de las actividades turísticas en la comunidad jemer alrededor de Bà Om Pond en Trà Vinh, Vietnam. A diferencia de trabajos anteriores que discutieron la belleza y el valor de la religión, los templos, la vida rural, los festivales y el arte jemer, esta investigación sostiene que las políticas centradas en las personas nunca han permitido que las personas alcancen sus objetivos.

Palabras clave: turismo; discurso del desarrollo; Khmer; Bà Om Pond; Trà Vinh.

\section{INTRODUCTION}

After the war, Vietnam implemented many development projects, such as hydroelectric power dams, irrigation systems, agricultural farms, etc., which obviously brought economic benefits and made Vietnam a rapidly developing country. People's lives, especially those of farmers, have been greatly improved. However, is the growth of the economy sufficient to compensate for the long-term loss of vision and its impact on nature and human spiritual life?

Lê (2007) once asserted that the current market economy in Vietnam has created many opportunities for getting rich quickly, but there are also many uncertain factors that make people seek spiritual comfort in the sacred worship. Bùi (2021) said that in today's Vietnam, people flatten hills and cut down trees to build temples. In fact, this is a 'business' investment, people build temples to meet spiritual needs and earn money. The discourse of making people "well fed and warmly dressed (cơm no áo âm)" has been used to explain the goal of these projects. In many cases, inappropriate policies have put economic and material values higher than spiritual values.

If the policy of transforming nature to benefit the people was the main movement in the postwar period, then a major change in concepts occurred in the early 21 st century. Development policy pays more attention to ecology, partly because of Vietnam's participation in international environmental protection treaties, and partly because of the rise of public opinion (through movies, volunteer movements, etc.). However, is it a true view of nature or a popular misunderstanding? Do people regard natural landscapes and non-humans as natural entities based on their objective principles or potential economic resources for the future exploitation?

The postwar period left major influences on the spiritual domain, including religious life. The so-called 'superstition' has dealt a great blow to religious institutions. In addition, the "religious reform policy has separated religious organisations from nature and regards nature as 'means' for reforming and establishing socalled 'religious civilisation'. The separation of religious communities and spiritual ecological spaces has produced many consequences, including the loss of indigenous wisdom and the degradation of local resources. This study at Bà Om Pond in Trà Vinh provides a typical example.

The name Bà Om Pond is derived from the worship of goddesses, not Buddhism, because the matriarchy has long existed in Khmer culture. Folk tales tell many legends and stories that explain the birth and name of the pond. Popular 
story tells that the Khmer practiced matriarchy, so married man had to come to live and work for his wife. This has caused controversy: should the couple live in a man's or a woman's home? In order to establish a good water supply to ensure survival and solve marital problems, the village held a pond digging competition. On the night of the competition, men thought that they were very strong and women would lose the game, so they were not in a hurry, but drank and danced until late at night, and then fell asleep. Under the command of Mrs. Om (Bà Om), women enthusiastically dug the pond all night. In the middle of the night, Mrs. Om put a chandelier on the branch. The sleeping men were taken aback, their eyes half-closed, thinking that the morning star was rising, so they gathered in the village temple and accepted the defeat. Since then, the Khmer people have continued to practice matriarchy in their family life, and the pond was named Bà Om Pond ${ }^{1}$.

On the traditional Khmer culture in the Mekong region, Phan (2009), Phan (2010), Bùi (2012), Le and Nguyen (2020), and others discussed the history, nature, community changes, and related aspects of village life. Most of these writers emphasised the role of Buddhist temples and monks in providing villagers with safe and healthy rural life. The Khmer traditionally respect the Buddha through the image of a monk, thereby respecting the things that belong to the Buddha (for example, temples, stupas, sacred ponds, gardens, and so on). However, so far, there has been no discussion about the government's ecological development policies and their impact on the religious space of Khmer communities.

As an initial hypothesis, the authors believe that the local authorities applied extensive nonspiritual development policies during the postwar periods, which separated the local Khmer community from the sacred pond sub-complex.

1 Story was told by Ms. T.S. and others, interview notes, 2019. See further Le and Nguyen (2020: 15).
This separation has led to the overall degradation of the local Buddhist landscape structure as a whole, causing the community to lose awareness and enthusiastic participation in environmental appreciation and protection. Obviously, the local authorities are trying to renovate and preserve the sacred pond landscape to benefit the community and improve the effectiveness of environmental protection in the area; however, such a policy essentially has the form of ecoambiguity. Once the sacred natural landscape is separated from the original Buddhist religious space, all efforts to protect and modify the value of the sacred landscape are useless. Inappropriate development discourse partially destroyed the organic structure and balance between humans and ecology in the local Khmer community of Trà Vinh City and directly degraded the value of indigenous knowledge that closely linked human life and ecology.

\section{METHODOLOGY}

This research uses an ethnic-cultural approach (ie, the Khmer people in southern Vietnam) and an ethnographic field survey method, focusing on investigating the spiritual ecology associated with the Khmer Buddhist temple complex in at the outskirts of Trà Vinh city. The discourse analysis in this study is based on both text analysis and field survey methods. Government policy documents and related academic discussions are fully used to show the development discourse developed by local governments in the past. Since 2012, the authors have begun to observe and evaluate the impact of local government development policies on the sacred pond complex and conducted an in-depth field survey at the end of 2019, which included 12 semi-structured and random in-depth interviews. Among the interviewees, there were 4 Khmer monks, 4 Khmer residents living near the sacred pond, 2 Vietnamese residents living in Trà Vinh urban area, and 2 local Vietnamese officials. The discourse analysis in this study is based on text analysis and field survey methods. 


\section{DISCUSSION}

\section{Ecoambiguity and the concept of ecology in East Asian philosophical systems}

East Asia, including Vietnam, is home to many philosophical systems that value the environment (Taoist and Confucian concepts of the unity of nature and man; Buddhist and Shinto views on the ecological ethics, etc.). However, compared to any other place in the world, the ecosystem in this region has been altered or destroyed for a longer period of time and on a larger scale (see Hyun and Kim, 2007).

The concept nature in equal status with human beings was once very clear in some of NeoConfucian ideology. Typically, the Song Chinese Confucian scholar Chang Tsai (1021-1077) once said:

"Heaven is my father and Earth is my mother, and even such a small creature as I find an intimate place in their midst. Therefore that which fills the universe I regard as my body and that which directs the universe I consider as my nature. All people are my brothers and sisters, and all things are my companions" ( $\mathrm{Tu}, 2001$ : 245).

However, in most cases, people usually do not regard nature as an equal entity. Thornber used the term "ecoambiguity" to describe this misleading behavior. Accordingly, "ecoambiguity" is "a concept that represents a complex and contradictory interaction between people and the environment with significant non-human existence" (Thornber, 2012: 1). Even if the governments and communities apply progressive environmental protection strategies, "the survival of many nature reserves and nonhuman habitats ultimately depend on human footprints" (Thornber, 2012: 1). So, ecoambiguity indicates and emphasises the ambivalence of human beings towards nature. Ecoambuiguity reflects the misunderstanding or confusion of the principles of non-human existence and its development. Being misled by such notions and behaviors, humans usually understate the role of the non-human world and accept its degradation. Although recent studies have shown that animals have certain emotions to some extent, the notion of non-emotional non-human existence and living beings is still widespread. In many cases, people inadvertently destroy the environmental landscape and animals they are trying to protect (Thorner, 2012: 2, 388).

Under this concept, the art of miniature artwork (such as bonsai) made by East Asians is a kind of ecoambiguity. In the landscape, the existence of rocks, water, and other microorganisms, we may feel that the owner loves nature and appreciates the beauty of nature at a glance. In fact, this is a misunderstanding. The garden owner, in reality, has changed nature on purpose and made nature serve his own hobbies. His attitude towards nature and desire to live in harmony with nature is absolutely not wrong, but making miniature landscapes intentionally changes the current natural conditions inherent in nature (landscapes, trees, water, etc.).

Chinese Confucian and Taoist scholars have connected miniature gardens with the shuimo painting, trying to "draw" and "shape" nature with their framed ideology. Confucianism pays more attention to social order and social development. Therefore, nature is essentially the environment and means for people to design and build an idealistic society. Karen Thornber highlighted that the concept of the Unity of Heaven and Man "more often defied than reflected empirical reality" (Thornber, 2021: 32). Heiner Roetz once assessed that sympathetic feeling for nature in ancient Chinese philosophies was just a simple reaction against what was actually happening (cited in Thornber, 2012: 19).

So is nature the equivalent companion of human life or the form of "tools" and "means" that serve humans? In nature reserves and "green" tourist resorts, the landscape has been violently adjusted and developed to meet the needs of travelers who want to see 'the beauty of nature'. 
Julia Ireland, in Thornber's (2012) citation, refers to this situation as "instrumentality" which is implicitly evident in development discourses of many countries.

Misleading views and behaviors about nature have a negative impact on human life and even human civilisation. Together with wars and climate change, the degradation of forests and arable land led to the decline of the ancient Mayan civilisations (Ponting (1991: 67-87; Thornber, 2012: 7-8). Similar situations have been found in the ancient Indus and Andean civilisations.

In Vietnam, in a study of comparative art and literature, Hoang discovered ecoambiguity and ideological/political discourses conveyed by Vietnamese commercial films (Hoang, 2020: 135-162). The author pointed out that in many films the great achievements of charity heroes in the national defense war were focused. The ecological landscape (bright blue sky and beautiful earth) was built as a revelation from Heaven and the protagonist, which shows that Heaven gave him the Heavenly Mandate to defeat enemies and rule the country. The ecological landscape and non-human elements have been well described, but in fact, it is still a political and ideological "tool", and many messages in it affirm the legitimacy and orthodoxy of the heroes and the new dynasties they built. It does not realise the true value of ecology in reality.

The new view of ecocriticism now opens the way for a new interpretation of the role of ecology in human life. In the 1990s, the world adopted a biology-centric approach in ecocriticism, and at the beginning of the 21 st century, it turned to a human-centered view (Thornber, 2012: 21). However, compared with human beings, neither of them puts nature in its inherent equal position. The Buddhist philosophy is identified as closest to the environment (Badiner, 1990) and classified into five different approaches: eco-apologist ecocritic, eco-constructivist, eco-ethicist, and ecocontextualist (Swearer, 2006: 125; Darlington, 2017: 489). In Buddhism, the concept of
Ahimsa is highly valued. The Buddhist sanghas (monks) strongly support the true state of all things, that is, the state of mutual balance, is constructed through the interconnection and mutual influence of elements (Badiner, 1990: xiv; Batchelor \& Brown, 1992: xiv). With the philosophy of wuwei (letting things take their own course), Taoists wholeheartedly cherishes the natural state of all things and people. They are constantly calling for the motto "flowers of every kind are in bloom" (Egri, 1997: 423). However, Buddhism and Taoism as a whole have not been regarded as the main axis of thought in East Asian societies. On the contrary, they added some moral categories to later Confucianism. The Vietnamese pay attention to both Confucianism and Mahayana Buddhism; however, it is obvious that the Vietnamese adopt Buddhist ideas mainly to satisfy their spiritual needs, not to apply them to the material life environment. On the other side, the Khmer community, the subject of this study, generally practices Theravada Buddhism. Therefore, in terms of life, especially ecology, there is a certain gap between the state management agency and the Khmer community.

\section{Theravada Buddhist temple space and Khmer indigenous knowledge in the Bà Om pond area}

Theravada Khmer Buddhism does not rule out the animism that has existed in their traditions for thousands of years, which enables them to create an experience of dealing with the natural environment through innovative principles based on Buddhist, Brahman philosophies and related rituals performed by Sanghas (see Phan 2010; Phan 2014). Almost every Khmer village has at least one Buddhist temple complex - a unique religious, cultural and social 'center' for the whole village. At the heart of the complex is the main hall, where Buddha Shakyamuni is worshipped. Sangha's accommodation buildings are built behind this building. A sacred pond (the cosmic pond, normally in square shape) symbolizing the 'ocean of milk' and the iconic symbol of the sacred Ganga River is located in the front of the 
main building. The pond itself is surrounded by longevity trees, making the landscape a copied version of the Buddha Lumbini garden. The pond is considered "sacred" and all monks and villagers have the ultimate responsibility to protect it. "Holy water" in the pond is only used for important rituals. Similarly, trees are also "sacred." Khmer people believe that gods, deceased ancestors, and wandering souls live under the shadow of trees and are protected by Buddha. Obviously, the pond and the garden are two integral parts of the entire temple complex.

Compared with other Khmer Buddhist temples in the region, Bà Om Pond and surrounding garden attached to Angkorajaborey Temple (Chùa Âng) are particularly large. The area of the pond and garden sub-complex is 5 hectares, and the pond itself is about 500 meters long and 300 meters wide. According to written texts stored in Angkorajaborey Temple and oral statements by local monks, the pond was dug at the end of the 10th century. In the garden, large shaded dipterocarpus alatus tree are planted, which has a deep root system that can bind the sand and keep it on the shore and, together with sand, they directly support the purification of pond water. Experts in cultural materialism explained that the village is located on a large sand dune and has not been submerged by the annual floods of the Mekong River (Le and Nguyen 2020: 1-40). Villagers often face water shortages during the dry season. In the past, people could only dig wells by hands in a small area. Bà Om Pond is larger in because this well must have ensured the freshwater supply for a large number of local Khmer residents. In 1994, Bà Om Pond Subcomplex was recognised as a national scenic spot.

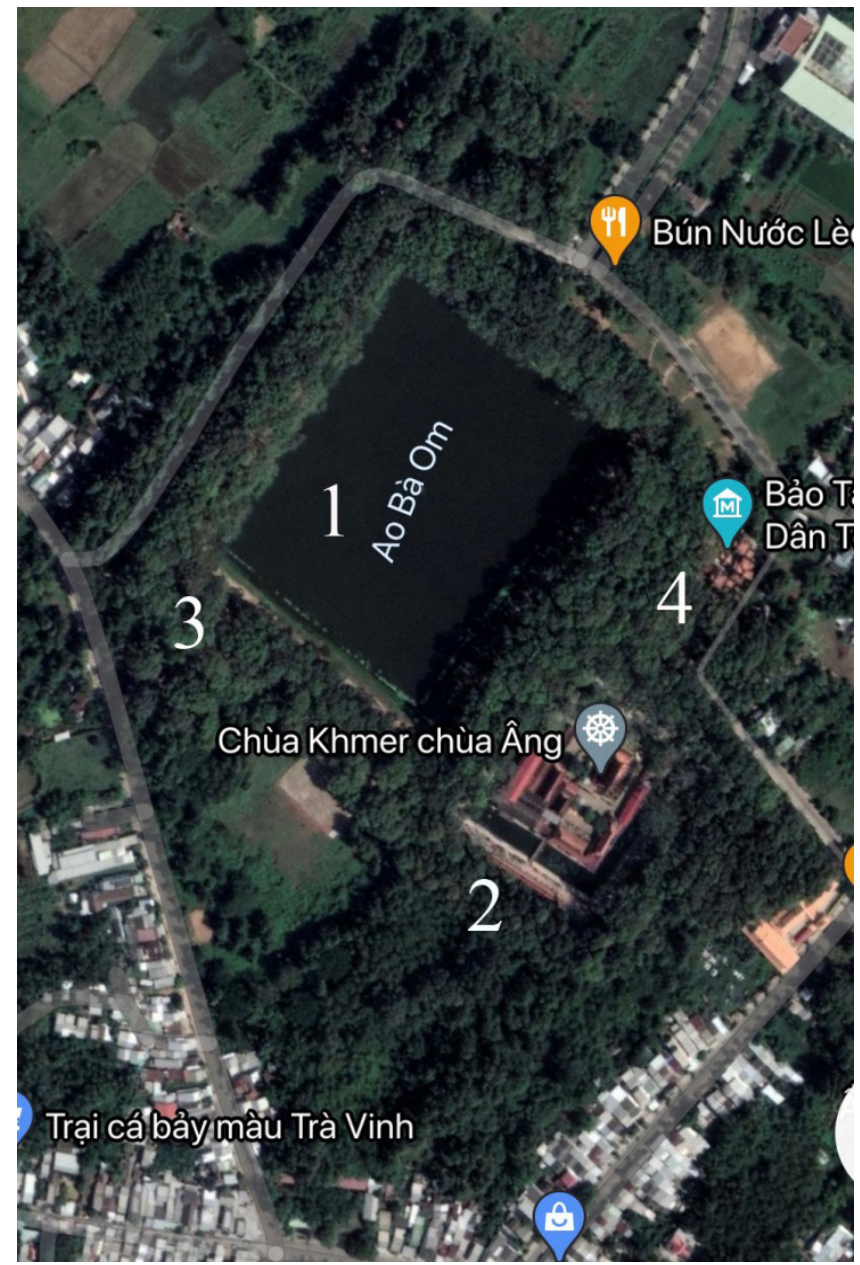

Figure 1: The Angkorajaborey Temple and Bà Om Pond Compex (Photo: Google Map, with authors' notes).

Notes:

1. Bà Om Pond

2. Angkorajaborey Temple

3. 'Lumbini' Garden

4. Museum of Ethnic Khmer Culture

It is evident that at the beginning, the pond subcomplex was created as a "tool" to ensure the survival of local community. To some extent, Ireland's concept of "instrumentality" is still accurate in this situation. The construction of the pond and the garden is basically a human action, that is, to partially renovate nature to create a more stable and sustainable living environment for humans. This 'instrumental' intervention is only a one-time action but its value is retained for a long time. With the passage of time, the community has adjusted its life according to the religious ecological space it created. Under the Buddhist faiths, they quickly regard this sub- 
complex as an important part of the religious institution where deities and ancestors shelter.

From the spiritual perspective, the belief in the sacredness of the Buddha's garden and the cosmic pond helps to connect the community with the temple and maintain the indigenous knowledge. This organisational structure also helps to strengthen the religious and cultural power of the Buddhist temples and sangha that own the sub-complex.

Beside Bà Om Pond (Female Pond), there is another public pond that ancient Khmer dug to store water: Ông Pond (Male Pond). According to local interviewees, this 1,100-square-meter pond is used for agricultural and living activities. Therefore, it has not been highly deified and strictly protected like Bà Om Pond. Today, the Ông Pond space has become a flat land, despite the many rumours said that the overwhelming violation of the pond's remains resulted in mysterious punishment. Apart from sugar palm trees, no other trees could survive on the site, and many families faced loss and failure when raising ducks in the 'sacred' area ${ }^{2}$.

\section{Discourse of tourism development and its impact on Bà Om Pond sub-complex}

Regarding the research issue, the post-war period in Vietnam can be divided into two periods, namely ethnic cultural development (1975-2000) and ehnic tourism development (2000 to present). Competent departments at all levels participated in the management policies and "reformed" ethnic culture in the first period. The nationalisation policy, the state-governed elimination of so-called "superstition" and the tightening of local management in the last two decades of the twentieth century pushed the ethnic Khmer away from their traditional ritual space. At that time, the local Khmer community only had full ownership of Angkorajaborey Temple, where people gathered together to

2 Interview notes, Mrs. D.T.X.T. and Ms. T.T.U. local residents, 2019. participate in Buddhist ceremonies. It should be noted that local authorities at that time still paid attention to the role of the water reserve in Bà $\mathrm{Om}$ Pond; specifically, in 1980, the local government renovated and dredged ponds, installed pipelines and pumped reserved water for use in the dry season. This is the driving force that further separated the community from the Bà Om Pond sub-complex ${ }^{3}$. For a long time thereafter, Bà Om Pond became a flat cattle-grazing land, and Ông Pond became an abandoned land ${ }^{4}$.

In teh second period, the policies of developing ethnic culture and ethnic ecology to develop tourism has greatly affected the Bà Om Pond ecological and cultural landscape and local Khmer ritual space., and "renovated" and "reconstructed" ethnic cultural relics and religious institutions, turning them into new types of "capital" for the development of tourism in the second one. The Bà Om Pond cultural complex has been used as a "capital".

The state constantly supplements and strengthens the policy of developing and exploiting ethnic cultural resources to develop tourism and benefit local communities. Accordingly, the ecological space associated with community culture is regarded as an integral part of the resources. Under the "instrumentality" viewpoint, ecology is now seen as a means to seek economic benefits. For example, the Ministry of Culture, Sports and Tourism has also formulated a "Tourism Product Development Strategy by 2025 and a Development Orientation by 2030" emphasizing "developing cultural tourism products closely related to heritage, festivals, excursions, and cultural research as well as lifestyles of the local people..." . Ethnic cultures from the northern mountains, the central highlands, and the Mekong Delta have recently been on this work agenda

3 Interview notes, Mr. L.N.T. (local Khmer resident), December 2019.

4 Interview notes, Mr. L.N.T, Mr. T.M., and Mr. S.N.K. (local Khmer residents), December 2019. 5 See Decision No. 2714 / QD-BVHTTDL dated August 3, 2016. 
Although the National Tourism Law clearly stipulates the task of protecting the ecology in the ecotourism industry, the intervention of local authorities in the ritual space and the separation of the community from its ritual space undermine the community's belief in the relics' sacredness as well as the role and value of the relics in the spiritual life of the community.

Tourism is considered to be one of the main fields that can benefit local communities and promote their material life in Trà Vinh. Compared with other provinces, Trà Vinh has less advantage in attracting tourists, mainly because of its remote location. However, the province has distinctive features of ethnic cultural diversity (Vietnamese, Khmer, and Chinese), among which Khmer culture is considered the most attractive factor for tourists. In 2019, 115,000 tourists visited the entire Bà Om Pond area (Trần and Phan, 2019: 5). This is the second most tourist attraction in the province, after Ba Động Beach by the sea. Therefore, in recent years, Trà Vinh Province has continuously made decisions about planning and developing the pond area into a tourist site. Accordingly, the entire Bà Om Pond subcomplex, Angkorajaborey Temple, and the Khmer Culture Museum, and four other nearby units are designed to form the Khmer Ethnic Cultural Village (see Võ and Phạm, 2019: 4). The People's Committee of Trà Vinh Province issued many decisions to achieve this goal. In 2014, Resolution No. 672/Decision QD-UBND on the project of "Tourism Development in 2015 and Direction in 2020 in Trà Vinh Province" was approved. Four years later, Resolution No. 70/2018/NQ-HDND on the establishment of a series of supporting policies in the field of tourism development in Trà Vinh Province from 2018 to 2020 was accepted. The first place on the list proves that Bà Om Pond plays the most important role in the entire project (see Võ and Phạm, 2019: 3).

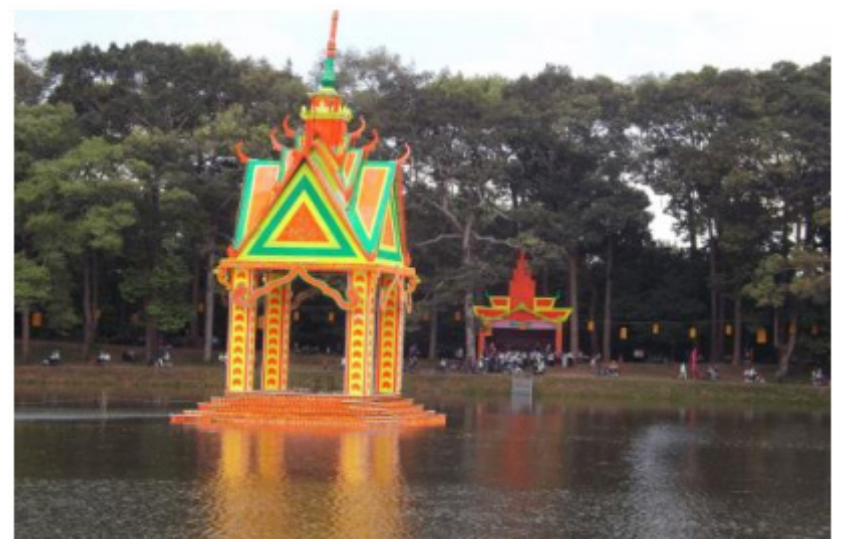

A Khmer temple built in the middle of Bà Om Pond (Photo: Võ and Phạm, 2019: 3)

Ecoambiguity has been proven in the local authorities' over-recognition of the potential of the pond sub-complex for tourism development. Local administrators and tourist agents highly evaluate the pond area's tourism potential, while local residents and tourists are skeptical of the integrity of the area's ritual space (Trần and Phan, 2019: 3). 96\% of officers and tourism agents voted for the Bà Om Pond complex to be invested as a tourist area while $86 \%$ of the mass (mainly Vietnamese) agreed this idea (Trần and Phan, 2019: 4). The study also emphasises that the Bà Om Pond sub-complex and Khmer OkOm-Bok Festival (Moon Worship Festival) held in this pond area are two "greatest heritages" for tourism development.

In order to promote tourism activities, by 2014, the local authorities ordered to dredge and repair the pond at a large scale. After that, a small colourful temple was built in the middle of the pond. They continued to plant lotus flowers (an element that easily drains the pond), release fish, and arrange some duck boats to serve the tourists. In other words, the renovated pond has become secularised in the new wave of tourism. Therefore, with the development of the staterun discourse "protecting the complexity of pond-garden relics, bringing economic value to the community and promoting the development of Khmer ethnic culture", the Bà Om Pond complex has lost its traditional role. In addition to the physical consequences of pollution and 
sandbank landslides, the renovation and tourism development has deeply disappointed local Khmer monks and many villagers. In their eyes, these activities have seriously "violated" their ritual space.

In the past, the Khmer had regularly performed rituals of offering sacrifice and flowers to the gods of the pond; however, this activity has strongly declined these days. Although nearby Angkorajaborey Temple is allowed to held rituals at the pond, its Buddhist ritual activities have shown changes in the direction of reduction. For example, the yearly wind-lamp festival is no longer held, and the lantern release ceremony is held on a much smaller scale ${ }^{6}$. To this extent, without the public sympathy and support, local development policy has become a false "capital" investment.

\section{Community response and solution suggestion}

This ecoambiguity causes a dull but profound response from the community. Moral issue has been raised among Khmer monks and certain residents living in the area. Rumours of punishment for those who violate the pond bed continue to circulate in the community. For example, some tourists fell in the pond from duck boats (and were rescued in time); somebody fell ill after trying to swim in the pond, etc. In particular, those who swim always feel that "there is something stubborn", so they can't swim $^{8}$. Similar rumours are aimed at careless tourists and local tourist merchants (Khmer and Vietnamese) who dump garbage and sewage into the pond. Surprisingly, all rumours highlight that only human violators are punished, animals such as ducks and swans swimming in the pond are absolutely safe! When asked, villagers did not know why. Only one monk told us that a conscious person should know what he can and cannot do, while ducks and swans are part of

$6 \quad$ Interview notes, monk T.T., Trà Vinh city.

7 The concept proposed by Bourdieu (1977).

8 Interviewed notes, Mr. T.S. and Ms. T.T.Đ.R, Châu Thành District, December 2019. the natural world, they don't know right from wrong9. When asked "who punishes?", villagers generally answered: "the Water God".

The most subtle and profound reaction is conveyed in the dream of "wandering in the lake" by Mr. T.S., a local Khmer intellectual. In the dream, a monk appeared from the pond bed invited him to visit the pond. The monk took him to the bottom of the pond. He realised that the life activities of "pond residents" were the same as those on the ground. Everyone had their work and lived in peace. According to him, the monk didn't say anything but delivered a clear message: "Our lives are just like you, we live a peaceful life. Do not violate the pond!" (interview notes, Mr. T.S., December 2019).

What can people do to overcome the ecoambiguity? Engels (1971) warned that we must never rule and cannot live outside the natural world; instead, we must understand the laws of nature and be able to use them correctly.

Ethnic ecology provides a source of indigenous wisdom, and it is still effective in today's modernisation and urbanisation era. Between 2016 and 2017, due to the depletion of water resources in the Mekong River (because of power dams in the upper reaches) and long-term drought, the freshwater supply in Trà Vinh City was depleted. At this time, only Bà Om Pond could still store a relatively large amount of freshwater. This incident greatly awakened the local authorities and residents. The ancestors of the Khmer wisely considered the shortage of freshwater 1,000 years ago, and they gave gods and 'pond residents' the 'responsibility' to protect the water - the lifeline of the community. Indigenous knowledge is still valuable, then the cultural and ecological relic should continue to be an integral part of the community's ecologicalhuman landscape.

9 However, the rumours that some families did not successfully raise ducks in Ông Pond ruins do not support this idea. 
Like in Lansing (1991) and Gellers (2000), the authors of this research believe that it is necessary to explain the indigenous knowledge and spiritual beliefs of habitat protection in the interaction with modern science to ensure its efficacy and sustainability. The sanctity of the Bà Om Pond area has been largely lost, and it is difficult to restore to its original state. People of the current political, social and cultural background cannot take ancient beliefs along with their lives.

We believe that this new approach can be implemented intwowaysat the same time:inspired from the inside and promoted from the outside. From an internal point of view, Angkorajaborey Temple and its Buddhist activities still exist and develop, more or less related to the Bà Om Pond sub-complex. Therefore, if used properly, the Buddhist ecological view is still effective for the restoration of the ritual space. Seligman and Weller (2012) emphasised that if we can establish a good notational system based on the morals and aspirations of the community and a series of appropriate rituals, participants will definitely gain shared experience. In a multicultural society, shared experience can generate power to enable people to cross boundaries, even if they don't have the same understanding and aspirations. As far as Khmer villagers near the Bà Om Pond area are concerned, they have almost similar moral standards and aspirations in the same tradition. Therefore, the effectiveness of sharing ritual experience in this group will definitely be higher than usual. On the other hand, traditional Theravada Buddhism has the ability to 'standardise' customs, and local Khmer monks can be the pioneers in reviving "standardised" communities and jointly protecting their traditional ecological landscape. "Buddhism and science are not only compatible but similar-perhaps even the same" (Cho, 2016: 687). Monks need to incorporate scientific knowledge into popular beliefs, folklore, and mythology in order to universalise customs and taboos. By doing so, monks can help raise public awareness of environmental protection and effectively abolish "unorthodox" magic stories and non-standard legends related to ponds. The "self-empowerment" of the local community must begin with pioneers' efforts. Last but not least, sanctified knowledge and community experience are closely related to real life. The rise of modernisation and technology has allowed people to observe and interpret "traditional" symbols in non-traditional ways (in applying Charles Pierce's (1931) semiotic concept of triadic relation), so, obviously, it is necessary to "renew" the symbolic value of each cultural reality in the community.

From the perspective of outsiders, especially local authorities, it is necessary to have an organic understanding of the objective existence and important role of the non-human world in human civilisation. Any development discourse must include an emphasis on absolute respect towards nature. Trà Vinh's tourism plan can only take effect when the concept of "moral economy" (Scott's (1976) concept) is effectively complied to prevent the ethnic culture erosion. As people with traditional Confucian civilisation, the Vietnamese authorities and ordinary people can gradually adopt the New Confucian concept of "anthropocosmism" and put it into practice. In the development discourse, the goal of benefiting local communities and the entire society is people-oriented. It must be based on the sustainability of ethnic culture and ecological landscape. "Anthropology" vision can function as one of the spiritual solutions to eliminate ecoambiguity.

\section{CONCLUSION}

Trà Vinh's traditional Khmer ethnic ecological landscape, the Bà Om Pond area, is an indispensable part of the community's Buddhist ritual space. After the war, national management policies removed the community from part of this ritual space and reduced community's belief in it. The recent tourism development plan focuses on the economic development of the community and the innovation and protection of the environment. The ethnic ecological landscape 
has been included in the discussions and included in work plans; however, as an objective world, ecology has not been properly evaluated. Instead, the Khmer ecological landscape has been largely used as a background and a means to benefit this community in inappropriate ways, which has led to various public responses. Therefore, in today's development discourse in Vietnam, ecoambiguity is a common issue. This "instrumental" mentality will continue to form the future policy and work agenda. In order to solve this ambiguity and non-spiritual policies, the self-cultivation and self-empowerment of the Khmer community to adapt to the new wave of development is very important. At the same time, this also requires the local authorities to reimagine their consciousness and behavior, especially the reassessment of the relationship between humans and non-humans. Before healing nature, one must first heal his mind.

\section{REFERENCE}

1. Badiner, A. H. (ed.). (1990). Dharma Gaia: A harvest of essays in Buddhism and ecology. Berkeley, CA: Parallax.

2. Batchelor, M. and Brown, K. (eds). (1992). Buddhism and ecology. London: Cassell.

3. Bourdieu, P. (1977). Cultural reproduction and social reproduction. In Power and ideology in education, ed. J. Karabel and A. H. Halsey, pp. 487-511. Oxford: Oxford University Press.

4. Bùi, U. (20021). "Việt Nam: Vạt núi đốn cây xây nơi thờ Phật 'vì tâm linh'?", BBCVietnamese, https://www.bbc.com/vietnamese/forum-56061077. Accessed on 25 February, 2021.

5. Cho, F. (2016). Buddhism and Science as Ethical Discourse. In The Oxford Handbook of Contemporary Buddhism, ed. Michael Jerryson, pp. 687- 98. Oxford handbooks online

6. Engels, F., (1971). Chống Đuyring (Anti-Dühring). Hanoi: Sự thật.

7. Darlington, S. M. (2017). Contemporary Buddhism and ecology. In The Oxford handbook of contemporary Buddhism, ed. Michael Jerryson, pp. 487-503. Oxford University Press.

8. Egri, C. P. (1999). Nature in Spiritual Traditions: Social and Cultural Implications for Environmental Change. In Living with Nature: Environmental Politics as Cultural Discourse, ed. Frank Fischer and Maarten Hajer, pp. 58-80. Oxford: Oxford University Press.

9. Gelles, P. H. (2000). Water and power in highland Peru: the cultural politics of irrigation and development. New Brunswick, N.J.: Rutgers University Press.

10. Hyun, I.T. \& Schreurs, M. eds. (2007). The Environmental Dimension of Asian Security: Conflict and Cooperation over Energy, Resources, and Pollution. Washington, DC: United States Institute of Peace Press.

11. Kinsley, R.D. (1995). Ecology and religion: ecological spirituality in cross-cultural perspective, Prentice Hall.

12. Lansing, S.J. (1991). Priests and programmers: technologies of power in the engineered landscape of Bali, Princeton, NJ: Princeton University Press.

13. Lê, H.L. (2007). "Praying for profit: The cult of the Lady of the Treasury (Bà Chúa Kho)", Journal of Southeast Asian studies, 38 (3): 493-514

14. Le, T.N.D. and Nguyen, N.T. (2020). "Spiritual Ecology and Environmental Protection: The Hidden Discourses of the Sacred Pond "Bà Om" of the Ethnic Khmer in Trà Vinh, Vietnam". In The Mekong History, Geology and Environmental Issues, ed. Simone Marseau, p. 1-40. New York: Nova Science Publishers.

15. Hoang, C.G. (2020). "Vietnamese and Chinese Movies about Royalty", Asian Studies, 8(2): 135162.

16. Phan, A. T. (2014). "Ứng xử với môi trường tự nhiên của người Khmer Nam Bộ nhìn từ sinh thái học Phật giáo (Conduct with the natural environment of the Khmer in the Southern Vietnam from the Buddhist ecology)", Studies on Religion 5 (131): 61 - 69.

17. Phan, T. Y. T. (2010). "Tâm thức ứng xử với nước của người Khmer qua lễ hội Ok Om Bok: tiếp cận sinh thái văn hóa (Behavioral perception with water source of the Khmer through Ok Om Bok festival: an approach of cultural ecology)", Journal of Science of Trà Vinh University, 7: 22-29.

18. Peirce, S.C. (1931). Collected papers, ed. Charles Hartshorne, Cambridge, MA.: Harvard University Press. 
19. Ponting, C. (1991). A green history of the world: the environment and the collapse of great civilisations. New York: St. Martin's Press.

20. Scott, J. C. (1976). The moral economy of the peasant: rebellion and subsistence in Southeast Asia. New Haven: Yale University Press

21. Segliman, B.A. \& Weller, P.R. (2012). Rethinking pluralism - ritual, experience, and ambiguity. Oxford: Oxford University Press.

22. Swearer, D. (2006). "An Assessment of Buddhist Ecophilosophy”, Harvard Theological Review, 99(2): 123-137.

23. Thornber, K. (2012). Ecoambiguity: Environmental Crises and East Asian Literatures. Ann Arbor: University of Michigan Press.

24. Trần, B.T. \& Phan, T.Đ. (2019). "Vai trò của di sản văn hóa - tài nguyên du lịch văn hóa đối với phát triển du lịch tỉnh Trà Vinh thực trạng và giải pháp (The role of cultural heritage-the status quo and solutions of cultural tourism resources to the development of tourism in Trà Vinh Province)", Conference Proceeding on Trà Vinh Tourism, Trà Vinh.

25. Tu, W.M. (2001). "The ecological turn in New Confucian humanisim: implications for China and the world", Agricultural \& Environmental Science Collection, 130(4): 243-264.

26. Võ Văn Sơn, Phạm Đào Ngọc Thảo. 2019. "Du lịch cộng đồng gắn với sinh kế hộ gia đình người Khmer ở Trà Vinh trong bối cảnh hiện nay (Community tourism related to the livelihoods of Trà Vinh Khmer families in the current situation)". Conference Proceeding on Trà Vinh Tourism, Trà Vinh. 